\title{
Blood shizonticidal activities of phenazines and naphthoquinoidal compounds against Plasmodium falciparum in vitro and in mice malaria studies
}

\author{
Nicolli Bellotti de Souza', Isabel M de Andrade1, Paula F Carneiro², Guilherme AM Jardim³, \\ Isadora MM de Melo ${ }^{3}$, Eufrânio N da Silva Júnior ${ }^{3} /{ }^{+}$, Antoniana Ursine Krettli ${ }^{1 /+}$ \\ 'Laboratório de Malária, Centro de Pesquisas René-Rachou-Fiocruz, Belo Horizonte, MG, Brasil ${ }^{2}$ Núcleo de Pesquisas de Produtos Naturais, \\ Universidade Federal do Rio de Janeiro, Rio de Janeiro, RJ, Brasil ${ }^{2}$ Laboratório de Química Sintética e Heterocíclica, \\ Departamento de Química, Instituto de Ciências Exatas, Universidade Federal de Minas Gerais, Belo Horizonte, MG, Brasil
}

Due to the recent advances of atovaquone, a naphthoquinone, through clinical trials as treatment for malarial infection, 19 quinone derivatives with previously reported structures were also evaluated for blood schizonticide activity against the malaria parasite Plasmodium falciparum. These compounds include 2-hydroxy-3-methylamino naphthoquinones (2-9), lapachol (10), nor-lapachol (11), iso-lapachol (12), phthiocol (13) and phenazines (12-20). Their cytotoxicities were also evaluated against human hepatoma and normal monkey kidney cell lines. Compounds 2 and 5 showed the highest activity against $\mathrm{P}$. falciparum chloroquine-resistant blood-stage parasites (clone W2), indicated by their low inhibitory concentration for $50 \%\left(I C_{50}\right)$ of parasite growth. The therapeutic potential of the active compounds was evaluated according to the selectivity index, which is a ratio of the cytotoxicity minimum lethal dose which eliminates $50 \%$ of cells and the in vitro $I C_{50}$. Naphthoquinones 2 and 5 , with activities similar to the reference antimalarial chloroquine, were also active against malaria in mice and suppressed parasitaemia by more than $60 \%$ in contrast to compound 11 which was inactive. Based on their in vitro and in vivo activities, compounds 2 and 5 are considered promising molecules for antimalarial treatment and warrant further study.

Key words: antimalarials - quinones - phenazines - lapachol - Plasmodium falciparum - Plasmodium berghei

To date, malaria remains a global health problem that affects 225 million people, mostly in tropical and subtropical regions of Africa and Southeast Asia (WHO 2011). A malaria vaccine is currently unavailable and chemotherapy remains the primary intervention for disease control; however, the resistance of Plasmodium falciparum to most antimalarial agents is increasing and in some regions of the world, the parasite is becoming resistant to artemisinin derivatives (Dondorp et al. 2009). In addition, the agent Plasmodium vivax has become resistant to chloroquine (Price et al. 2009, Graf et al. 2012, Marques et al. 2014), further raising difficulties of controlling malaria. More effective compounds and new treatment strategies are therefore needed, particularly drugs with high therapeutic indexes, novel and/or defined mechanisms of action, easy synthesis and activity against all stages of malarial parasitic infection.

Quinone-based compounds with antimalarial activity, such as hydrolapachol (Hooker 1936) and lapachol, which are both isolated from plants (Fieser \& Fieser 1948), have been studied in depth over recent decades. Interest in the

\footnotetext{
doi: 10.1590/0074-0276130603

Financial support: CAPES, CNPq/FAPEMIG, MCT/CNPq/CT-

Saúde/MS/SCTIE/DECIT (480719/2012-8, 480719/2012-8), Project

Universal MCTI/CNPq (14/2012) (480719/2012-8), UFMG (to ENSJ)

+ Corresponding authors: akrettli@cpqrr.fiocruz.br, eufranio@ufmg.br

Received 30 December 2013

Accepted 5 May 2014
}

antimalarial properties of hydroxy-naphthoquinones has increased since the development of atovaquone (Fry \& Pudney 1992, Srivastava et al. 1997), a commercially available drug for malaria chemoprophylaxis (Shapiro et al. 1999) that is used to treat $P$. falciparum malaria (McKeage \& Scott 2003) in areas with chloroquine resistance (Aguiar et al. 2012, WHO 2012). These compounds also possess antibacterial and antitumor activities due to their effects on oxidative stress (Lourenço et al. 2011, Cavalcanti et al. 2013).

Phenazines are produced through the heterocyclisation of naphthoquinoidal structures and also possess antimicrobial (van Rensburg et al. 2000), antiviral (Wang et al. 2000) and antimalarial (Makgatho et al. 2000, Andrade-Neto et al. 2004b) activities.

Some quinoidal molecules have demonstrated an improved biological response in relation to their parent compounds due to their increased lipophilicity (de Castro et al. 2013); however, the low bioavailability of atovaquone (Dressman \& Reppas 2000) indicates the need for chemical modifications, especially in the alkyl group, to produce new analogues (Schuck et al. 2013). Furthermore, increasing resistance to atovaquone has been reported (Vaidya \& Mather 2000, Fivelman et al. 2002).

In this study, we modified the alkyl side chain of atovaquone to create naphthoquinone derivatives containing tertiary amine substitutions (Fig. 1), which were also previously shown to have antimicrobial (Carneiro et al. 2011) and antitumoural (da Silva Júnior et al. 2011) properties. These derivatives were synthesised using the classic Mannich reaction from lawsone and 
evaluated against $P$. falciparum blood parasites in vitro. Compounds were next classified by their selective activity, with the exclusion of toxic compounds. In addition, some phenazines were similarly obtained and evaluated. The compounds with the highest activity and a low toxicity profile in vitro were next evaluated against malaria infection in mice. This study thus reinforces the importance of this class of compounds as treatment for parasitic diseases including P. falciparum.

\section{MATERIALS AND METHODS}

Chemistry - 2-hydroxy-3-methylamino naphthoquinoidal compounds 2-9 were prepared from lawsone by the classic Mannich reaction, using the appropriate amines and formaldehyde in an alcohol-based solution (Fig. 1) as previously described (Leffler \& Hathaway 1948, Lagrota et al. 1988, dos Santos et al. 2000, Lima et al. 2002). The obtained derivatives were then characterised as previously described (Lagrota et al. 1988, dos Santos et al. 2000, Lima et al. 2002) (Fig. 2).

Lapachol (10) was extracted from the heartwood of Tabebuia sp. (Tecoma) and purified by a series of recrystallisation steps (Pinto et al. 1980). Nor-lapachol (11) was obtained using the Hooker oxidation method (Fieser \& Fieser 1948). Iso-lapachol (12) and 2-hydroxy3-methyl-1,4-naphthoquinone (13) were both synthesised using previously described techniques (Hooker 1936). Phenazine 14 was prepared from lapachol (10) through a two-step process (da Silva Júnior et al. 2009). Compound 15 was obtained from reduced nor-lapachol. Lapachol (10) was catalytically reduced and used to obtain compound 16 using the same reaction (da Silva Júnior et al. 2011) and compound 17 was obtained through a similar process. The phenazine compounds 18-20 were prepared from C-allyl lawsone as previously described (da Silva Júnior et al. 2011) (Fig. 3).

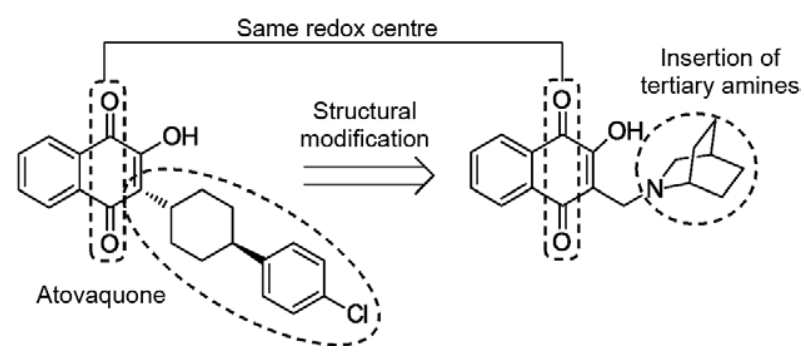

Fig. 1: strategy toward bioactive quinone derivatives.
Cytotoxicity tests with human hepatocellular liver carcinoma cell line (HepG2) - HepG2 (ATT, USA), kindly donated by Universidade Nova de Lisboa, Portugal, and normal monkey kidney cells (BGM) cells, donated by the University of Minas Gerais, were cultured in RPMI-1640 medium (Sigma-Aldrich, USA, ref 6504), containing $40 \mathrm{mg} / \mathrm{L}$ gentamicin (ScheringPlough, USA) and $10 \%$ heat-inactivated foetal calf serum in $5 \% \mathrm{CO}_{2}$ at $37^{\circ} \mathrm{C}$ (Gibco, USA). After reaching confluence, the cell monolayer was then trypsinised, washed with culture medium, aliquoted into a flat-bottomed 96-well plate (Corning, USA, ref 3595) at $5 \times 10^{3}$ cells/well and incubated for $18 \mathrm{~h}$ at $37^{\circ} \mathrm{C}$ to allow cell adhesion. The test and control compounds were added at various concentrations $(188-4,324 \mu \mathrm{M})$ and the cell monolayer was incubated for another $24 \mathrm{~h}$. Cytotoxicity was next evaluated as described (Coutinho et al. 2013) with the [3-(4,5-dimethylthiazol-2-yl)-2,5 diphenyltetrazolium bromide] (MTT) assay by adding $20 \mu \mathrm{L}$ of $5 \mathrm{mg} / \mathrm{mL}$ MTT (Molecular Probes, USA) per well (Denizot \& Lang 1986). After $3 \mathrm{~h}$ of incubation, the supernatant was discarded, $100 \mu \mathrm{L}$ of dimethyl sulfoxide (DMSO) (Sigma-Aldrich) were added per well and the optical density was measured (SpectraMax 340PC384, Molecular Devices, USA) at $570 \mathrm{~nm}$ for the test conditions and $630 \mathrm{~nm}$ for the background wells. Cell viability was expressed as a percentage of the absorbance of the untreated control cells subtracted from the appropriate background measurement. The minimum lethal dose of $50 \%$ cells $\left(\mathrm{MLD}_{50}\right)$ was determined as previously described (de Madureira et al. 2002) and further used to calculate the selectivity index (SI) of the active compounds, defined as the ratio of the $\mathrm{MLD}_{50}$ to the $\mathrm{IC}_{50}$ (Bézivin et al. 2003).

Continuous culture of P. falciparum and in vitro tests of drug activity - Blood-stage parasites from the chloroquine-resistant and mefloquine-sensitive $P$. falciparum W2 clone kept as described (Andrade-Neto et al. 2004a) were maintained at $37^{\circ} \mathrm{C}$ in human erythrocytes $\left(\mathrm{A}^{+}\right)$ in complete medium (RPMI-1640, supplemented with $10 \%$ blood group $\mathrm{A}^{+}$human serum) that was changed daily as previously described (Trager \& Jensen 1976). The effects of the compounds were determined relative to control parasites kept in culture medium only (Rieckmann et al. 1978). Ring-stage sorbitol-synchronised parasites (Lambros \& Vanderberg 1979) were used after adjusting the parasitaemia and haematocrit values as specified in each test at a volume of $180 \mu \mathrm{L} /$ well in 96-well microtitre plates (Corning, ref. 3595) contain-<smiles>[R]CC1=C(O)C(=O)c2ccccc2C(=O)C1=O</smiles>

(2)

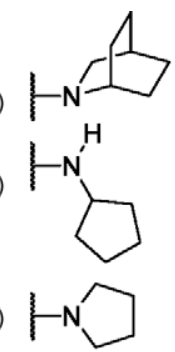

(5)

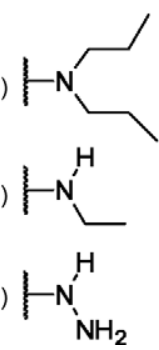

(8)

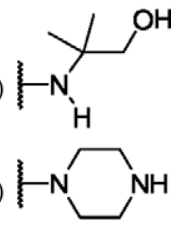

Fig 2: naphthoquinones 2-9 obtained by Mannich reaction. 
<smiles>CC(C)=CCC1=C(O)C(=O)c2ccccc2C1=O</smiles><smiles>CC(C)=CC1=C(O)C(=O)c2ccccc2C1=O</smiles><smiles>CC(C)/C=C/C1=C(O)C(=O)c2ccccc2C1=O</smiles><smiles>CC1=C(O)C(=O)c2ccccc2C1=O</smiles>

Phthiocol (13)<smiles>CC(=O)C=CC1(Oc2c(CC=C(C)C)c3ccccc3c3nc4ccccc4nc23)C(=O)C(=O)c2ccccc2C1=O</smiles><smiles>CC(C)CC1=C(OC2(CC(C)C)C(=O)c3ccccc3-c3nc4ccccc4nc32)C(=O)c2ccccc2C1=O</smiles>

(15)<smiles>CC(C)CCC1=C(OCC2(CCC(C)C)NC3=Nc4ccccc4C(=O)C3C2=O)c2ccccc2C1=O</smiles>

(16)<smiles>CC(C)CCc1c2[nH]c3ccccc3nc-2c2c(c1=O)CCCC2</smiles>

(17)<smiles></smiles>

(18)<smiles>C=CCC1=C(OC2C(=O)c3ccccc3C3=Nc4ccccc4NC32)C(=O)c2ccccc2C1=O</smiles>

(19)<smiles>CCCC1=C(OC2(CCC)C(=O)c3ccccc3-c3nc4ccccc4nc32)C(=O)c2ccccc2C1=O</smiles>

(20)

Fig. 3: lapachol (10), nor-lapachol (11), iso-lapachol (12), phthiocol (13) and phenazine compounds 14-20.

ing the diluted compounds in triplicate. The drug activity was measured using the anti-histidine-rich protein II (HRPII) test (Noedl et al. 2002). Chloroquine was used as the antimalarial control in each test.

For the HRPII test, the parasites were adjusted to $0.05 \%$ parasitaemia and $1.5 \%$ haematocrit, placed in plates containing the drugs and incubated for $24 \mathrm{~h}$ under standard culture conditions. The contents of six wells (containing no test drugs) were harvested and frozen in microtubes for later use as background measurement. After $48 \mathrm{~h}$ of incubation, the plates were frozen at $-70^{\circ} \mathrm{C}$ and thawed twice. Next, $100 \mu \mathrm{L}$ of the lysed cells from each well were added to a plate that had been pre-coated overnight at $4^{\circ} \mathrm{C}$ with the primary anti-HRPII antibody (MPFM-55A, ICLLAB ${ }^{\circledR}$, USA) for immunoassay. Phosphate-buffered saline at $\mathrm{pH} 7.2$ supplemented with Tween 20 (Sigma-Aldrich) (0.05\%) and bovine serum albumin (Sigma-Aldrich) (4\%) was used to block the plates to (avoid non-specific antibody binding) for $3 \mathrm{~h}$ at room temperature (RT). After $1 \mathrm{~h}$ at RT, the plates were washed and $100 \mu \mathrm{L} /$ well secondary antibody solution (MPFG55P ICLLAB ${ }^{\circledR}$ ) were added, followed by incubation with 3,3',5,5'-tetramethylbenzidine chromogen cat. \#50-7600 (KPL, USA) in the dark. The reaction was stopped by adding $1 \mathrm{M}$ sulphuric acid and the absorbance was read $(450 \mathrm{~nm})$ using a spectrophotometer (SpectraMax 340PC384, Molecular Devices). Anti-P. falciparum drug activity was measured by comparing the drug concentrations that inhibited parasite growth to drug-free control cultures, which were representative of $100 \%$ cell growth.

Growth data from the serial drug dilutions to sigmoidal dose-response curves was analysed by curve-fitting software (Microcal Origin Software v.5.0, OriginLab Co, USA) and used to measure inhibitory concentration for $50 \%\left(\mathrm{IC}_{50}\right)$ of parasite growth. Only compounds exhibiting $\mathrm{IC}_{50}$ values lower than $5 \mu \mathrm{M}$ were considered active; those with $\mathrm{IC}_{50}$ values between 5-30 $\mu \mathrm{M}$ were considered partially active and those with $\mathrm{IC}_{50}$ values higher than 30 $\mu \mathrm{M}$ were considered inactive compounds.

Antimalarial tests against Plasmodium berghei in mice - The antimalarial suppressive test was performed as previously described (Peters et al. 1975) with slight modifications (Andrade-Neto et al. 2004b). Briefly, P. berghei (NK65) chloroquine-sensitive blood-stage parasites were stored at $-70^{\circ} \mathrm{C}$ and passaged weekly in outbred Swiss mice. Adult female mice weighing $20 \pm 2 \mathrm{~g}$ were inoculated with $1 \times 10^{5}$ infected erythrocytes, randomly distributed into groups of three mice per group after $24 \mathrm{~h}$ infection and then drug treated daily by gavage for three consecutive days. All compounds were freshly diluted in $3 \%$ DMSO in RPMI medium and used at doses of $100 \mathrm{mg} /$ $\mathrm{kg}$; chloroquine was used at $20 \mathrm{mg} / \mathrm{kg}$ and control mice received the drug vehicle. At days 5 and 9 after parasite inoculation, blood was taken from the tails of the mice and used to prepare smears, which were then fixed with methanol, Giemsa-stained and examined microscopically to determine parasitaemia as previously described (AndradeNeto et al. 2004b). The inhibition of parasite growth by drug treatment was evaluated in relation to the untreated mice, which were representative of $100 \%$ parasite growth. Compounds that reduced parasitaemia by more than $40 \%$ were considered active, whereas those that reduced parasitaemia by $30-40 \%$ or less than $30 \%$ were classified as partially active and inactive, respectively. 
Ethics - The protocols for animal use in the laboratory were previously approved by the Ethical Committee for Animal Use (L-0046/08), Oswaldo Cruz Foundation, Brazil.

\section{RESULTS}

Eight 2-hydroxy-3-methylamino naphthoquinones, seven phenazines and lapachol, nor-lapachol, iso-lapachol and phtiocol were evaluated for their in vitro activity against $P$. falciparum blood-stage parasites. All compounds were assayed using the anti-HRPII test. The standard antimalarial chloroquine was tested as a control agent in parallel and the data are summarised in Table I.

Among the compounds tested, napthoquinones 2 and 5 were active, exhibiting $\mathrm{IC}_{50}$ values $<5 \mu \mathrm{M}$ (1.3 and 1.9 $\mu \mathrm{M}$, respectively). Compounds 3, 4, 5, 7, nor-lapachol (11) and iso-lapachol (12) were considered partially active, as well as the phenazines $16-18$ with $\mathrm{IC}_{50}$ within the range of 5 and $30 \mu \mathrm{M}$. The other compounds were considered inactive, exhibiting $\mathrm{IC}_{50}$ values $>30 \mu \mathrm{M}$.

Regarding cytotoxicity against both HepG2 and BGM cells, all molecules exhibited no toxicity based on high $\mathrm{MLD}_{50}$ values observed. Only compound 8 was toxic to both cell lines.
Considering the therapeutic potential of the molecules examined, which was defined as the SI based on the cytotoxicity against HepG2 cells and antiplasmodial activity in vitro, compounds 2 and 5 exhibited the highest SI values of 2,564 and 1,074, respectively, which were similar to or higher than that of chloroquine $(\mathrm{SI}=1,535)$. Seven other molecules exhibited promising SIs ranging from 100-350; these compounds were iso-lapachol (12), three naphthoquinones derived from lawsone $(3,4,6)$ and two phenazines (17 and 18). Nor-lapachol (11), the naphthoquinone compound 7 , the phenazines prepared from lapachol $(14,16)$ and phenazine (19) derived from $\mathrm{C}$-allyl lawsone were less active $(\mathrm{SI}<100)$. Other compounds displayed a low SI $(10,13,15$ and 20$)$ and were thus less promising; one compound (8) exhibited an SI value of 10 and was considered toxic. A near two-fold increase in cytotoxicity between HepG2 and BGM cells was observed for compounds $12,15,19$ and 20.

To determine the in vivo activity of the selected compounds, 2, 5 and 11 were next evaluated against malaria infection caused by $P$. berghei. Both compounds were found to be active by reducing parasitaemia by up to $63 \%$, whereas nor-lapachol (compound 11) was inactive in vivo (Table II). Analysis of the experimental compounds was

TABLE I

Activity of quinones and phenazines against Plasmodium falciparum inhibitory concentration for $50 \%\left(\mathrm{IC}_{50}\right)$ measured through the anti-histidine-rich protein II (HRPII) method, cytotoxicity [minimum lethal dose of 50\% cells $\left(\mathrm{MLD}_{50}\right)$ ] against two different cell lines a human hepatoma (HepG2) and a normal monkey kideny (BGM) and selectivity indexes (SI) a ratio $\mathrm{MDL}_{50} / \mathrm{IC}_{50}$

\begin{tabular}{|c|c|c|c|c|c|}
\hline \multirow[b]{2}{*}{ Compounds } & \multirow[b]{2}{*}{$\mathrm{IC}_{50}$} & \multicolumn{2}{|c|}{ HepG2 } & \multicolumn{2}{|c|}{ BGM } \\
\hline & & $\mathrm{MLD}_{50}$ & SI & $\mathrm{MLD}_{50}$ & SI \\
\hline 2 & $1.3 \pm 0.4$ & $\geq 3,363.1$ & 2,564 & $\geq 3,363.1$ & 2,564 \\
\hline 3 & $16.8 \pm 3.4$ & $\geq 3,685.8$ & 220 & $\geq 3,685.8$ & 220 \\
\hline 4 & $14.1 \pm 7.0$ & $\geq 3,886.7$ & 276 & $\geq 3,886.7$ & 276 \\
\hline 5 & $1.9 \pm 0.7$ & $2,075.1 \pm 316.5$ & 1,074 & $2,468.4 \pm 239.7$ & 1,299 \\
\hline 6 & $30.6 \pm 5.7$ & $\geq 4,324.4$ & 141 & $\geq 4,324.4$ & 141 \\
\hline 7 & $11.2 \pm 2.3$ & $331.1 \pm 105.3$ & 29 & 256.6 & 23 \\
\hline 8 & $59.9 \pm 7.7$ & $188.0 \pm 34.7$ & 3 & $321.5 \pm 28.3$ & 5.4 \\
\hline 9 & $110.4 \pm 12.2$ & $2,497.6 \pm 546.9$ & 23 & $\geq 3,672.4$ & 33 \\
\hline 10 & $93 \pm 20,5$ & $1,491.7 \pm 321.4$ & 16 & $1,785.1 \pm 888.3$ & 19 \\
\hline 11 & $26.9 \pm 0.9$ & $1,698.6 \pm 94.8$ & 63 & $1,608.8 \pm 221.8$ & 60 \\
\hline 12 & $12.7 \pm 2.0$ & $\geq 4,127.6$ & 324 & $1,388.9 \pm 592.5$ & 109 \\
\hline 13 & $\geq 265.7$ & $5,308.2 \pm 8.3$ & 20 & $\geq 5,314.1$ & 20 \\
\hline 14 & $47.5 \pm 1.1$ & $\geq 1,803$ & 38 & $\geq 1,803$ & 38 \\
\hline 15 & $\geq 94.2$ & $1,041.0 \pm 58.5$ & 11 & $\geq 1,884.6$ & 20 \\
\hline 16 & $20.6 \pm 2.6$ & $951.6 \pm 115.6$ & 46 & $632.8 \pm 11.4$ & 31 \\
\hline 17 & $9.0 \pm 0.1$ & $\geq 3,120.8$ & 348 & - & - \\
\hline 18 & $13.4 \pm 2.2$ & $\geq 3,492.5$ & 260 & $\geq 3,492.5$ & 260 \\
\hline 19 & $60.5 \pm 9.2$ & $\geq 2,005.9$ & 33 & $752 \pm 169.9$ & 12 \\
\hline 20 & $\geq 99.5$ & $\geq 1,989.8$ & 20 & $1,047.6 \pm 43.6$ & 10 \\
\hline Chloroquine & $0.3 \pm 0.02$ & $460.4 \pm 97.3$ & 1,535 & $462.3 \pm 2.7$ & 1,541 \\
\hline
\end{tabular}




\section{TABLE II}

Antimalarial activity of nor-lapachol (11) and of the naphthoquinones 2 and 5 active in vitro, tested in mice with Plasmodium berghei-malaria and orally treated with $100 \mathrm{mg} / \mathrm{kg}$ drug dose for three consecutive days

\begin{tabular}{lccc}
\hline & \multicolumn{3}{c}{$\begin{array}{c}\text { Inhibition of parasitaemia } \\
\text { at days after parasite inoculation } \\
(\%)\end{array}$} \\
\cline { 2 - 4 } Compounds $^{a}$ & Fifth & Ninth & Activity \\
\hline 2 & 63 & 41 & Yes \\
5 & 63 & 48 & Yes \\
11 & 21 & 21 & No \\
Chloroquine & 100 & 100 & Cure \\
\hline
\end{tabular}

$a$ : the experiment was performed in parallel with chloroquine, which cleared parasitaemia and allowed all mice to survive after treatment with a $20 \mathrm{mg} / \mathrm{kg}$ dose.

performed once and in parallel to chloroquine, which served as a control antimalarial agent, clearing parasitaemia even at low doses $(20 \mathrm{mg} / \mathrm{kg})$ and maintaining survival of the mice. The other treated animals succumbed to malaria infection with no delay in mortality caused by drug treatment with the new compounds.

\section{DISCUSSION}

The synthetic strategy for the preparation of the 2-hydroxy-3-methylamino naphthoquinoidal derivatives (2-9) was used to obtain substances with aliphatic (5-8) and cyclic (2-4 and 9) substituents (Lima et al. 2002, da Silva Júnior et al. 2012). This approach mimics the nonpolar portion of atovaquone. The quinoidal compounds were prepared in only one step using accessible reactants. The structures of these naphthoquinonoid compounds have been previously published, although our study is the first to report their potent activity against $P$. falciparum parasites. The synthetic methods described in this study were completed with commercial reactants and at high yields for quinoidal structures based on atovaquone. These compounds were prepared through a single step synthesis in contrast to the production of atovaquone, which is generally obtained in four steps. The phenazine compounds were easily prepared from lapachol derivatives and their activities have been described as antitumoural (da Silva Júnior et al. 2011) and antimicrobial (Carneiro et al. 2011).

Our results showed that compounds 2 and 5 were active against $P$. falciparum in vitro, exhibiting high SIs and promising therapeutic activity, similar to that of chloroquine. We considered the SI an ideal parameter to evaluate new antimalarials, as this index reflects both drug toxicity and activity, thereby excluding toxic compounds from further study. Using the SI as a screening parameter has also been reported in recent literature (No et al. 2012).

Establishing a structure-activity relationship for the compounds herein described was beyond the scope of this initial study. Investigations into the antimalarial activity of these compounds after structural modification are currently underway in our laboratories and will be reported in future work after establishing a structure-activity relationship.

Compounds 2 and 5, which were highly active in vitro against $P$. falciparum, were also active against malaria in mice by inhibiting parasitaemia; however, they could not prevent mortality from malaria. All compounds were tested at high doses because previous studies have indicated that lapachol has low activity in vitro (Carvalho et al. 1988) compared with the new compounds described. All displayed a low in vivo activity compared do chloroquine. It is possible that these compounds possess low oral bioavailability, similar to most naphthoquinones (Ioset 2008). In addition, slow uptake and/or rapid elimination of their active metabolites have also been previously described (Zani et al. 1997).

In previous work, other phenazines derived from $\beta$-lapachone partially active against $P$. falciparum in vitro were only active against malaria in mice when administered subcutaneously, but not orally (Andrade-Neto et al. 2004b). Compounds 2 and 5 had a high therapeutic activity in vitro were tested only through oral administration in malaria-infected mice. These compounds were active despite limiting our study to oral administration.

The mechanism of quinone activity involves the generation of reactive oxygen species due to molecular structures that confer redox properties through reduction by one or two electrons. Oxidative stress and/or the alkylation of lipids, proteins and nucleic acids by naphthoquinones may lead to cell damage (Vilamil-Fernandez et al. 2004), which accounts for their antimalarial (dos Santos et al. 2004) and antileukemic (Cavalcanti et al. 2013) activities. The ability to collapse mitochondrial membrane potential has also been described for atovaquone (Srivastava et al. 1997) and other naphthoquinones active against $P$. falciparum (Schuck et al. 2013), a process that eventually leads to apoptosis or necrosis (Brand et al. 2004). Whether the mechanism of action of these molecules is related to such processes remains to be determined.

The cytotoxicity profiles were similar for all molecules using BGM or HepG2 cell lines. The two-fold differences observed for compounds 12, 15, 19 and 20 may be related to the distinct cellular processes exhibited by these two cells lines, which may have altered their sensitivity to the compounds.

In conclusion, among the 19 compounds evaluated for anti- $P$. falciparum activity, the naphthoquinones derived from lawsone (compounds 2 and 5) showed the highest activities with $\mathrm{IC}_{50}$ values $<5 \mu \mathrm{M}$. They also showed the highest therapeutic effects which were similar to or higher than that of chloroquine. In addition, the cytotoxicities of the majority of the tested compounds were low. Importantly, compounds 2 and 5 were shown to be active in vivo against malaria, causing a greater than $50 \%$ reduction of parasitaemia in mice infected with $P$. berghei. These compounds therefore show promise in the search for new antimalarial agents, with activities similar to that of atovaquone. 


\section{ACKNOWLEDGEMENTS}

To Profs Antonio V Pinto (in memoriam) and Maria do Carmo FR Pinto, for stimulating discussions and consistently excellent advice.

\section{REFERENCES}

Aguiar ACC, da Rocha EMM, de Souza NB, França TCC, Krettli AU 2012. New approaches in antimalarial drug discovery and development: A Review. Mem Inst Oswaldo Cruz 107: 831-845.

Andrade-Neto VF, Brandão MGL, Oliveira FQ, Casali VWD, Njaine B, Zalis MG, Oliveira LA, Krettli AU 2004a. Antimalarial activity of Bidens pilosa L. (Asteraceae) ethanolic extracts from wild plants collected in various localities or plants cultivated in humus soil. Phytother Res 18: 634-639.

Andrade-Neto VF, Goulart MFO, Silva-Filho JF, Matusalém JS, Pinto MCFR, Pinto AV, Zalis MG, Carvalho LH, Krettli AU 2004b. Antimalarial activity of phenazines from lapachol, $\beta$-lapachone and its derivatives against Plasmodium falciparum in vitro and Plasmodium berghei in vivo. Bioorg Med Chem Lett 14: 1145-1149.

Bézivin C, Tomasi S, Dévéhat Fl, Boustie J 2003. Cytotoxic activity of some lichen extracts on murine and human cancer cell lines. Phytomedicine 10: 499-503.

Brand MD, Affourtit C, Esteves TC, Green K, Lambert AJ, Miwa S, Parker N 2004. Mitochondrial superoxide: production, biological effects and activation of uncoupling proteins. Free Radic Biol Med 37: 755-767.

Carneiro PF, Pinto MC, Coelho TS, Cavalcanti BC, Pessoa C, de Simone CA, Nunes IK, de Oliveira NM, de Almeida RG, Pinto AV, de Moura KC, da Silva PA, da Silva Júnior EN 2011. Quinonoid and phenazine compounds: synthesis and evaluation against $\mathrm{H}_{37}$ $\mathrm{Rv}$, rifampicin and isoniazid-resistance strains of Mycobacterium tuberculosis. Eur J Med Chem 46: 4521-4529.

Carvalho LH, Rocha EM, Raslan DS, Oliveira AB, Krettli AU 1988. In vitro activity of natural and synthetic naphthoquinones against erythrocytic stages of Plasmodium falciparum. Braz J Med Biol Res 21: 485-487.

Cavalcanti BC, Barros FW, Cabral IO, Ferreira JR, Magalhães HI, Júnior HV, da Silva Júnior EN, de Abreu FC, Costa CO, Goulart MO, Moraes MO, Pessoa C 2011. Preclinical genotoxicology of nor- $\beta$-lapachone in human cultured lymphocytes and Chinese hamster lung fibroblasts. Chem Res Toxicol 24: 1560-1574.

Cavalcanti BC, Cabral IO, Rodrigues FAR, Barros FWA, Rocha DD, Magalhães HIF, Moura DJ, Saffi J, Henriques JAP, Carvalho TSC, Moraes MO, Pessoa C, de Melo IMM, da Silva Júnior EN 2013. Potent antileukemic action of naphthoquinoidal compounds: evidence for an intrinsic death mechanism based on oxidative stress and inhibition of DNA repair. J Braz Chem Soc 24: 145-163.

Coutinho JP, Aguiar ACC, dos Santos PA, Lima JC, Rocha MGL, Zani CL, Alves TMA, Santana AEG, Pereira MM, Krettli AU 2013. Aspidosperma (Apocynaceae) plant cytotoxicity and activity towards malaria parasites. Part I: Aspidosperma nitidum (Benth) used as a remedy to treat fever and malaria in the Amazon. Mem Inst Oswaldo Cruz 108: 974-982.

da Silva Júnior EN, Cavalcanti BC, Guimarães TT, Pinto MCFR, Cabral IO, Pessoa C, Costa-Lotufo LV, Moraes MO, Andrade CKZ, Santos MR, Simone CA, Goulart MOF, Pinto AV 2011. Synthesis and evaluation of quinonoid compounds against tumor cell lines. Eur J Med Chem 46: 399-410.

da Silva Júnior EN, Melo IMM, Diogo EBT, Costa VA, de Souza Filho JD, Valença WO, Camara CA, Oliveira RN, Araújo AS, Emery FS, Santos MR, Simone CA, Menna-Barreto RFS, Castro SL 2012. On the search for potential anti-Trypanosoma cruzi drugs: synthesis and biological evaluation of 2-hydroxy-3-methylamino and 1,2,3-triazolic naphthoquinoidal compounds obtained by click chemistry reactions. Eur J Med Chem 52: 304-312.

da Silva Júnior EN, Pinto MCFR, de Moura KCG, de Simone CA, Nascimento CJ, Andrade CKZ, Pinto AV 2009. Hooker's lapachol peroxide revisited. Tetrahedron Lett 50: 1575-1577.

de Castro SL, Emery FS, da Silva Júnior EN 2013. Synthesis of quinoidal molecules: strategies towards bioactive compounds with an emphasis on lapachones. Eur Med Chem 69: 678-700.

de Madureira MC, Martins AP, Gomes M, Paiva J, Cunha AP, Rosário V 2002. Antimalarial activity of medicinal plants used in traditional medicine in S. Tomé and Príncipe islands. J Ethnopharmacol 81: 23-29.

Denizot F, Lang R 1986. Rapid colorimetric assay for cell growth and survival. Modifications to the tetrazolium dye procedure giving improved sensitivity and reliability. J Immunol Methods 89: 271-277.

Dondorp AM, Nosten F, Yi P, Das D, Phyo AP, Tarning J, Lwin KM, Ariey F, Hanpithakpong W, Lee SJ, Ringwald P, Silamut K, Imwong M, Chotivanich K, Lim P, Herdman T, An SS, Yeung S, Singhasivanon P, Day NP, Lindegardh N, Socheat D, White NJ 2009. Artemisinin resistance in Plasmodium falciparum malaria. N Engl J Med 361: 455-467.

dos Santos AF, Ferraz PAL, Pinto AV, Pinto MCFR, Goulart MOF, Sant'Ana AEG 2000. Molluscicidal activity of 2-hydroxy-3alkyl-1,4-naphthoquinones and derivatives. Int $J$ Parasitol 30: 1199-1202.

dos Santos EVM, Carneiro JWM, Ferreira VF 2004. Quantitative structure-activity relationship in aziridinyl-1,4-naphthoquinone antimalarials: study of theoretical correlations by the PM3 method. Bioorg Med Chem 12: 87-93.

Dressman JB, Reppas C 2000. In vitro-in vivo correlations for lipophilic, poorly water-soluble drugs. Eur J Pharm Sci 11 (Suppl.): S73-S80.

Fieser LF, Fieser M 1948. Naphthoquinone antimalarials. XII. The Hooker oxidation reaction. J Am Chem Soc 70: 3215-3222.

Fivelman QL, Butcher GA, Adagu IS, Warhurst DC, Pasvol G 2002. Malarone treatment failure and in vitro confirmation of resistance of Plasmodium falciparum isolate from Lagos, Nigeria. Malar J 1: 1.

Fry M, Pudney M 1992. Site of action of the antimalarial hydroxynaphthoquinone, 2-[trans-4-(4'-chlorophenyl) cyclohexyl]3-hydroxy-1,4-naphthoquinone (566C80). Biochem Pharmacol 43: $1545-1553$.

Graf PCF, Durand S, Antonio CA, Montalvan C, Montoya MG, Green MD, Santolalla ML, Salas C, Lucas C, Bacon DJ, Fryauff DJ 2012. Failure of supervised chloroquine and primaquine regimen for the treatment of Plasmodium vivax in the Peruvian Amazon. Malar Res Treat 2012: 1-5.

Hooker SC 1936. The constitution of lapachol and its derivatives. The structure of Paterno's iso-lapachol. J Am Chem Soc 59: 1190-1195.

Ioset JR 2008. Natural products for neglected diseases: a review. Curr Org Chem 12: 643-666.

Lagrota MHC, Wigg MD, do Santos MGM, Pinto AV, Pinto MCFR 1988. Atividade antivirótica de naftoquinonas: II. Derivados 1,4naftoquinônicos frente a enterovírus. Rev Microbiol 19: 338-342.

Lambros C, Vanderberg JP 1979. Sychronization of Plasmodium falciparum erythrocytic stages in culture. J Parasitol 65: 418-420.

Leffler MT, Hathaway RJ 1948. Naphthoquinone antimalarials; 2-hydroxy-3-substituted-aminoethyl derivatives by the Mannich reaction. J Am Chem Soc 70: 3222-3223.

Lima NMF, Correia CS, Ferraz PAL, Pinto AV, Pinto MCRF, Santana AEG, Goulart MOF 2002. Molluscicidal hydroxynaphthoquinones and derivatives. Correlation between their redox 
potentials and activity against Biomphalaria glabrata. J Braz Chem Soc 13: 822-829.

Lourenço AL, Abreu PA, Leal B, da Silva Jr EN, Pinto AV, Pinto MCFR, Souza AMT, Novais JS, Paiva MB, Cabral LM, Rodrigues CR, Ferreira VF, Castro HC 2011. Identification of nor- $\beta$ lapachone derivatives as potential antibacterial compounds against Enterococcus faecalis clinical strain. Curr Microbiol 62: 684-689.

Makgatho ME, Anderson R, O'Sullivan JF, Egan TJ, Freese JA, Cornelius N, van Rensburg CEJ 2000. Tetramethylpiperidine-substituted phenazines as novel anti-plasmodial agents. Drug Dev Res 50: $195-202$.

Marques MM, Costa MR, Santana Filho FS, Vieira JL, Nascimento MT, Brasil LW, Nogueira F, Silveira H, Reyes-Lecca RC, Monteiro WM, Lacerda MV, Alecrim MG 2014. Plasmodium vivax chloroquine resistance and anemia in the western Brazilian Amazon. Antimicrob Agents Chemother 58: 342-347.

McKeage K, Scott L 2003. Atovaquone/proguanil: a review of its use for the prophylaxis of Plasmodium falciparum malaria. Drugs 63: 597-623.

No JH, Dossin FM, Zhang Y, Liu YL, Zhu W, Feng X, Yoo JA, Lee E, Wang K, Hui R, Freitas-Junior LH, Oldfield E 2012. Lipophilic analogs of zoledronate and risedronate inhibit Plasmodium geranylgeranyl diphosphate synthase (GGPPS) and exhibit potent antimalarial activity. Proc Natl Acad Sci USA 109: 4058-4063.

Noedl H, Wongsrichanalai C, Miller R, Myint K, Looareesuwan S, Sukthana Y, Wongchotigul V, Kollaritsch H, Wiedermann G, Wernsdorfer W 2002. Plasmodium falciparum: effect of antimalarial drugs on the production and secretion characteristics of histidine-rich protein II. Exp Parasitol 102: 157-163.

Peters W, Portus JH, Robinson BL 1975. The four-day suppressive in vivo antimalarial test. Ann Trop Med Parasitol 69: 155-171.

Pinto MCFR, Pinto AV, Oliveira CGT 1980. Síntese de naftoquinonas naturais a partir do lapachol. An Acad Bras Cienc 52: 481-482.

Price RN, Douglas NM, Anstey NM 2009. New developments in Plasmodium vivax malaria: severe disease and the rise of chloroquine resistance. Curr Opin Infect Dis 22: 430-435.
Rieckmann K, Campbell G, Sax L, Mrema J 1978. Drug sensitivity of Plasmodium falciparum. An in vitro microtechnique. Lancet 1: 22-23.

Schuck DC, Ferreira SB, Cruz LN, da Rocha DR, Moraes M, Nakabashi M, Rosenthal PJ, Ferreira VF, Garcia CR 2013. Biological evaluation of hydroxynaphthoquinones as anti-malarials. Malar J 12: 234-239.

Shapiro TA, Ranasinha CD, Kumar N, Barditch-Crovo P 1999. Prophylactic activity of atovaquone against Plasmodium falciparum in humans. Am J Trop Med Hyg 60: 831-836.

Srivastava IK, Hagai R, Akhil BV 1997. Atovaquone, a broad spectrum antiparasitic drug, collapses mitochondrial membrane potential in a malarial parasite. $J$ Biol Chem 272: 3961-3966.

Trager W, Jensen JB 1976. Human malaria parasites in continuous culture. Science 193: 673-675.

Vaidya AB, Mather MW 2000. Atovaquone resistance in malaria parasites. Drug Resist Updat 3: 283-287.

van Rensburg CE, Joone GK, Sirgel FA, Matlola NM, O'Sullivan JF 2000. In vitro investigation of the antimicrobial activities of novel tetramethylpiperidine-substituted phenazines against $M y$ cobacterium tuberculosis. Chemotherapy 46: 43-48.

Vilamil-Fernandez S, Stoppani AOM, Dubin M 2004. Redox cycling of $\beta$-lapachoneand strutural analogues in microsomal and cytosol liver preparations. Methods Enzymol 378: 67-87.

Wang W, Préville P, Morin N, Mounir S, Cai W, Siddiqui MA 2000. Hepatitis C viral IRES inhibition by phenazine and phenazinelike molecules. Bioorg Med Chem Lett 10: 1151-1154.

WHO - World Health Organization 2011. World Malaria Report. Available from: who.int/malaria/world_malaria_report_2011/en/.

WHO - World Health Organization 2012. World Malaria Report. Available from: who.int/malaria/publications/world_malaria report_2012/en/.

Zani CL, Chiari E, Krettli AU, Murta SM, Cunningham ML, Fairlamb AH, Romanha AJ 1997. Anti-plasmodial and anti-trypanosomal activity of synthetic naphtho[2,3-b]thiopen-4,9-quinones. Bioorg Med Chem 12: 2185-2192. 